\title{
Accidental Fire in the Cerrado: Its Impact on Communities of Caterpillars on Two Species of Erythroxylum
}

\author{
Cintia Lepesqueur, ${ }^{1}$ Helena C. Morais, ${ }^{2}$ and Ivone Rezende Diniz ${ }^{3}$ \\ ${ }^{1}$ Programa de Pós-Graduação em Ecologia, Instituto de Ciências Biológicas, Universidade de Brasília, 70910-900 Brasília, DF, Brazil \\ ${ }^{2}$ Departamento de Ecologia, Instituto de Ciências Biológicas, Universidade de Brasília, 70910-900 Brasília, DF, Brazil \\ ${ }^{3}$ Departamento de Zoologia, Instituto de Ciências Biológicas, Universidade de Brasília, 70910-900 Brasília, DF, Brazil
}

Correspondence should be addressed to Cintia Lepesqueur, bioclg@gmail.com

Received 9 August 2012; Accepted 9 October 2012

Academic Editor: Helena Maura Torezan-Silingardi

Copyright (c) 2012 Cintia Lepesqueur et al. This is an open access article distributed under the Creative Commons Attribution License, which permits unrestricted use, distribution, and reproduction in any medium, provided the original work is properly cited.

Among the mechanisms that influence herbivorous insects, fires, a very frequent historical phenomenon in the cerrado, appear to be an important modifying influence on lepidopteran communities. The purpose of this study was to compare the richness, abundance, frequency, and composition of species of caterpillars in two adjacent areas of cerrado sensu stricto, one recently burned and one unburned since 1994, on the experimental farm "Fazenda Água Limpa" (FAL) (1555'S and 47 55’ W), DF, Brazil. Caterpillars were surveyed on two plant species, genus Erythroxylum: E. deciduum A. St.-Hil. and E. tortuosum Mart. (Erythroxylaceae). We inspected a total of 4,196 plants in both areas, and 972 caterpillars were found on $13.3 \%$ of these plants. The number of plants with caterpillars (frequency) differed significantly between the areas. The results indicate that recent and accidental fires have a positive effect on the abundance of caterpillars up to one year postfire, increase the frequency of caterpillars associated with Erythroxylum species in the cerrado and do not affect the richness of caterpillars on these plants. Moreover, the fires change the species composition of caterpillars by promoting an increase in rare or opportunistic species.

\section{Introduction}

Systems represented by the associations of plants and insects include more than one-half of the world's multicellular species. The impacts of disturbances, anthropogenic or otherwise, affect the characteristics of communities of herbivorous insects in any biome worldwide [1]. There is strong evidence that these disturbances result in complex changes in the interactions between plants and herbivores [2]. Fires affect communities of herbivorous insects and provide opportunities for changes in species richness, abundance and species composition in space and time [3]. Among herbivores, Lepidoptera can serve as good indicators of environmental changes caused by these disturbances in certain habitats [4].

Fires in the cerrado are a natural phenomenon of recognized ecological importance [5] and occur during the dry season, from May to September $[6,7]$. The effects of fire on the structure, composition and diversity of plants in the cerrado are far more extensively documented [8-12] than the effects on the fauna [13-15]. The knowledge of the effects of fire on insect herbivores and their natural enemies is even more limited $[3,16,17]$.

The general literature on the responses of insects to fire in comparison with the responses to other forms of management in open habitats indicates that a significant decrease of insects occurs soon after a fire. The magnitude of the decrease is related to the degree of exposure to flames and to the mobility of the insect [18]. In cerrado, a very rapid and vigorous regrowth of vegetation occurs [19] and this regrowth may favor an increase in the abundance of herbivores. The caterpillar community in the cerrado is species rich and the abundance of most species is low but is highly variable throughout the year $[20,21]$, due primarily to the climate variability that characterizes the two seasons (dry and wet) in the region. This pattern has also been observed for herbivorous insects in New Guinea. It is characteristic of the herbivorous insect communities in general and is also 
typical of tropical regions [22]. Among the mechanisms that influence these herbivorous insect community patterns, fires, a very frequent historical phenomenon in the cerrado, appear to be an important modifying influence on lepidopteran communities.

The objective of this study was to compare the richness, relative abundance, frequency, and species composition of caterpillars between two cerrado areas, one recently burned and one unburned since 1994. The study hypotheses that the richness, relative abundance, frequency, and species composition of the caterpillars on the host plants vary between recently burned areas and areas without recent burning (used as a control). We predict that the abundance and species richness of caterpillars will increase significantly in a recently burned area as a result of the intense regrowth of vegetation in the postfire environment [19]. The postfire environment differs greatly from the prefire environment because of the higher phenological synchrony of plants and because of changes in microclimate result from to increased exposure to the sun.

\section{Methodology}

External folivorous caterpillars were surveyed on two plant species, Erythroxylum deciduum A. St.-Hil. and E. tortuosum Mart. (Erythroxylaceae), in two adjacent areas of cerrado sensu stricto, on the experimental farm "Fazenda Água Limpa" (FAL) $\left(15^{\circ} 55^{\prime} \mathrm{S}\right.$ and $\left.47^{\circ} 55^{\prime} \mathrm{W}\right)$, DF, Brazil. Both plant species were abundant and had similar size in the burned and unburned areas. This system, including only two plant species in the genus and their caterpillars, was chosen for study due to the need for simplification in the analysis and reduction of variables. This choice also reflected the ease of collection and identification and the prior knowledge of the system in the protected areas of the cerrado. The two plant species occur at high densities in the cerrado region and their lepidopteran fauna is known from previous studies in unburned areas [20,23]. An accidental fire affected the entire area in 1994, and the area suffered another accidental fire in August 31, 2005. The area burned in 1994 was viewed as a control, and the area burned in 2005 was considered recently burned. Data were collected from September 2005 through August 2006.

In both study areas (recently burned and control), external folivorous caterpillars were collected weekly from foliage of 50 individuals of each of the two species of plants. All caterpillars were collected, photographed, numbered as morphospecies, and individually reared in the laboratory in plastic pots (except for gregarious caterpillars), with leaves of the host plant as a food. The adults obtained from laboratory rearing were, as far as possible, identified and deposited in the Entomological Collection, Departamento de Zoologia, Universidade de Brasilia.

A binomial test of two proportions was applied with a significance level of 0.05 to evaluate the occurrence of a consistent difference in the proportion of plants with caterpillars (relative abundance and species richness) between the areas [24]. Species rarefaction curves were constructed to analyze the species richness of caterpillars in each area [25]. EcoSim
TABLE 1: Number of plants with caterpillars, abundance, and richness of caterpillars on two species of Erythroxylum, in two areas of cerrado sensu stricto in the FAL (burned and control areas) from September 2005 to August 2006.

\begin{tabular}{lccc}
\hline \multirow{2}{*}{ Variables } & \multicolumn{2}{c}{ Areas } & \multirow{2}{*}{ Total } \\
& Control (\%) & Burned (\%) & \\
\hline Inspected plants & $2,065(49.2)$ & $2,131(50.8)$ & 4,196 \\
Plants with caterpillars & $226(10.9)$ & $333(15.6)$ & 559 \\
Abundance of caterpillars & $346(35.6)$ & $626(64.4)$ & 972 \\
Richness of caterpillars & $29(59.0)$ & $36(74.0)$ & $47^{*}$ \\
\hline
\end{tabular}

* Species richness is not the sum total of the richness of the two areas because some species occur in both areas.

7.0 software was used to construct these curves based on 1000 replications [26].

The Shannon-Wiener index $\left(H^{\prime}\right)$, Simpson index $(D)$ and Berger-Parker index $\left(D_{\mathrm{bp}}\right)$ were used to compare the diversity and dominance of the community of caterpillars on Erythoxylum in the two study areas. The indices were obtained with DivEs 2.0 software [27]. The Jaccard similarity index was also applied to evaluate the degree of similarity of the species composition of two communities. If the Jaccard index is equal to one ( $B=0$ and $C=0)$, all species are shared between the two communities. If the Jaccard index is near 0 , few if any species are shared.

\section{Results}

We inspected a total of 4,196 plants, with similar numbers in both areas (Table 1). A total of 972 caterpillars were found on $13.3 \%$ of the plants inspected. The number of plants with caterpillars (frequency) differed significantly between areas $(p 1=0.11 ; p 2=0.16 ; Z=-4.46 ; P<0.001)$. The probability of finding a plant with a caterpillar in the control area (one out of nine plants inspected) was smaller than in the burned area (one to six plants). The relative abundance of caterpillars also differed significantly $(p 1=0.17, p 2=0.30$, $Z=-9.69, P<0.001)$ between areas. Almost twice as many caterpillars were found in the burned area as found in the control area (Table 1).

Forty-seven species or morphospecies (hereafter treated as species) of caterpillars were recorded, belonging to at least 15 families (two species belonged to unidentified families). The burned area had 36 species, compared with 29 species in the control area (Table 1). However, this difference in species richness between the areas was not significant $(p 1=0.08$; $p 2=0.06 ; Z=1.57 ; P>0.05)$. Even after adjustment by the rarefaction method to a common basis of an equal number of caterpillars in both areas $(n=346)$ the species richness did not differ, and the estimated number of species varied between 24 and 32 (Table 2; Figure 1).

The value of dominance was higher in the burned area $(34.5 \%)$ than in the control area (29.8\%) (Table 2). Likewise, the dominance for the burned area, estimated by rarefaction, was between $31.2 \%$ and $37.9 \%$, significantly higher than the value estimated for the control area on a common basis of 346 caterpillars in both areas (Table 2). These results are 
TABLE 2: Diversity of caterpillars on two species of Erythroxylum in two areas of cerrado sensu stricto in the FAL (recently burned and control) from September 2005 to August 2006: number of caterpillars, species richness, estimated species richness through rarefaction in the control area $(n=346,95 \%$ confidence interval), dominant species and dominance observed in both areas, estimated dominance by rarefaction in the control area $(n=346,95 \%$ confidence interval), diversity index $\left(H^{\prime}\right)$, and dominance $(D$ and $\left.D_{\text {bp }}\right)$.

\begin{tabular}{lcc}
\hline & Control area & Burned area \\
\hline $\begin{array}{l}\text { Number of caterpillars } \\
\text { Observed species richness }\end{array}$ & 346 & 626 \\
$\begin{array}{l}\text { Estimated richness } \\
\text { Rarefaction, } n=346)\end{array}$ & - & 36 \\
$\begin{array}{l}\text { Dominant species } \\
\text { Observed dominance }\end{array}$ & $29.8 \%$ & $24-32$ \\
$\begin{array}{l}\text { Expected dominance } \\
\text { Diversity of }\end{array}$ & - & Antaeotricha sp. \\
Shanon-Wiener $\left(H^{\prime}\right)$ & 1.01 & $34.5 \%$ \\
$\begin{array}{l}\text { Dominance of Simpson }(D) \\
\text { Dominance of }\end{array}$ & 0.16 & 0.89 \\
Berger-Parker $\left(D_{\mathrm{bp}}\right)$ & 0.30 & 0.21 \\
\hline
\end{tabular}

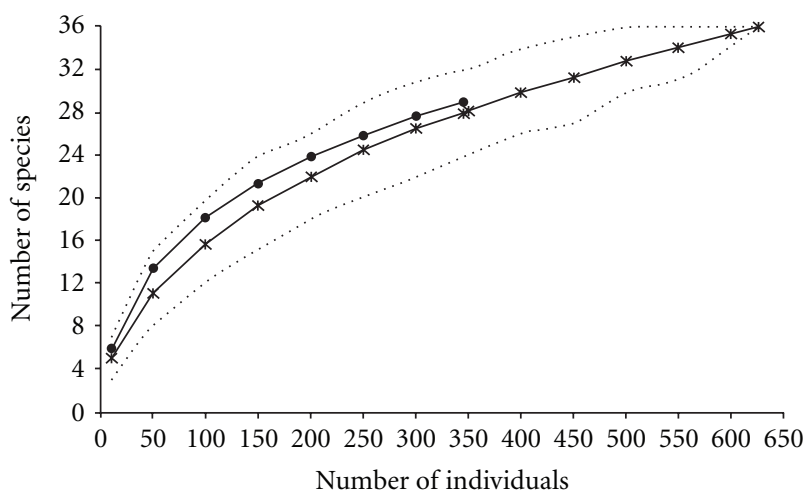

FIGURE 1: Rarefaction curves of caterpillar species of the control area (line with circle) and the burned area (line with star) in relative to the number of individuals estimated from randomizations of the order of 1000 samples in cerrado sensu stricto in the FAL from September 2005 to August 2006. The dotted line indicates 95\% confidence intervals.

also consistent with the dominance index values $D$ and $D_{\mathrm{bp}}$, which were higher in the burned area. The diversity index $H^{\prime}$ was higher in the control area (Table 2).

An unidentified species of Antaeotricha (Elachistidae) was dominant, with $29.7 \%$ and $34.5 \%$ of the individuals found in the control and burned areas, respectively. Ten species recorded in the control area showed intermediate dominance, between 1.2 and $7.5 \%$, whereas six species showed intermediate dominance in the burned area, with values between 1.1 and $8.0 \%$. The proportion of rare species, those represented by less than $1 \%$ of all caterpillars, was significantly higher $(p 1=0.55, p 2=0.75, Z=-1.68$,
TABLe 3: Abundance of caterpillars and Jaccard similarity index between the two areas of cerrado sensu stricto in the FAL (recently burned and control) from September 2005 to August 2006 based on caterpillars found on two species of Erythroxylum.

\begin{tabular}{lccc}
\hline \multicolumn{3}{c}{ Abundance } & Jaccard index \\
Months & $\begin{array}{c}\text { Control } \\
\text { area }\end{array}$ & $\begin{array}{c}\text { Burned } \\
\text { area }\end{array}$ \\
\hline Sep & 16 & 0 & 0.00 \\
Oct & 12 & 17 & 0.22 \\
Nov & 3 & 7 & 0.20 \\
Dec & 12 & 30 & 0.29 \\
Jan & 31 & 40 & 0.70 \\
Feb & 16 & 27 & 0.50 \\
Mar & 12 & 33 & 0.27 \\
Apr & 26 & 42 & 0.25 \\
May & 132 & 242 & 0.33 \\
Jun & 51 & 144 & 0.62 \\
Jul & 26 & 37 & 0.29 \\
Aug & 9 & 7 & 0.00 \\
\hline Total & 346 & 626 & 0.38 \\
\hline
\end{tabular}

$P<0.05)$ in the burned area $(n=27)$ than in the control area $(n=16)$.

The similarity between the study areas was low $(\mathrm{Sj}=$ $0.38)$, even on a monthly basis, with January $(S j=0.70)$ and June $(S j=0.62)$ being the sole exceptions (Table 3 ). Of the 47 species recorded, $38.3 \%$ ( $n=18$ species $)$ were common to the two areas (Table 4 ), and $25.5 \%$ of the species $(n=12)$ were restricted to the control area. The species restricted to the control area included the gregarious moth Hylesia shuessleri Strand, 1934 (Saturniidae) and the solitary Dalcerina tijucana (Schaus, 1892) (Dalceridae), both dietary generalists (Table 4). Approximately $40 \%$ of the species ( $n=18$ ) were found only in the burned area. These species included Fregela semiluna (Walker, 1854) (Arctiidae), a generalist species, and Eloria subapicalis (Walker, 1855) (Noctuidae) a dietary specialist. The effects of the fire appear to be more evident for Limacodidae as five of the eight species of this family found in the survey occurred exclusively in the control area. Certain species, however, appear to benefit from the effects of fire, for example, three species of Noctuidae found exclusively in the burned area: Cydosia mimica (Walker, 1866), Cydosia punctistriga (Schauss, 1904) and Noctuidae sp. The five most abundant species (more than 15 individuals per area) were found in both areas and are apparently restricted to the Erythroxylaceae in the region (Table 4).

No caterpillars were found on species of Erythroxylum until one month after the fire (Table 3). However, the relative abundance of caterpillars was higher in the burned area in all of the following months. Until 12 months after the occurrence of the fire, the caterpillar relative abundance in the burned remained higher than the abundance found in the control area (Figure 2). The temporal occupation of the species of Erythroxylum by caterpillars resulted in a pattern whose abundance and richness gradually increased with 
TABLE 4: Families and species of caterpillars found on two species of Erythroxylum in burned and control areas of cerrado in the FAL from September 2005 to August 2006 (NI = no information about diet breadth; polyphagous = feeds on species from two or more families of plants; restricted $=$ feeds only on species of Erythroxylaceae)

\begin{tabular}{|c|c|c|c|c|}
\hline Family & Species & Control area & Burned area & Diet breadth \\
\hline \multirow{2}{*}{ Arctiidae } & Fregela semiluna (Walker, 1854) & 0 & 4 & Polyphagous \\
\hline & Paracles sp. & 6 & 2 & Polyphagous \\
\hline \multirow{5}{*}{ Dalceridae } & Acraga infusa (Schauss, 1905) & 4 & 2 & Polyphagous \\
\hline & Acraga sp. 1 & 0 & 1 & NI \\
\hline & Acraga sp. 2 & 0 & 2 & NI \\
\hline & Dalceridae sp. & 0 & 1 & $\mathrm{NI}$ \\
\hline & Dalcerina tijucana (Schauss, 1892) & 1 & 0 & Polyphagous \\
\hline \multirow{2}{*}{ Elachistidae } & Antaeotricha sp.* & 103 & 216 & Restricted \\
\hline & Timocratica melanocosta (Becker, 1982) & 2 & 3 & Polyphagous \\
\hline \multirow{6}{*}{ Gelechiidae } & Dichomeris sp. 1 & 1 & 10 & Restricted \\
\hline & Dichomeris sp. 2 & 22 & 6 & Polyphagous \\
\hline & Dichomeris sp. $3^{*}$ & 26 & 160 & Restricted \\
\hline & Dichomeris sp. 4 & 3 & 8 & Polyphagous \\
\hline & Dichomeris spp. (duas espécies)* & 68 & 84 & Restricted \\
\hline & Gelechiidae sp.* & 44 & 50 & Restricted \\
\hline \multirow{5}{*}{ Geometridae } & Cyclomia mopsaria (Guenée, 1857)* & 16 & 24 & Restricted \\
\hline & Geometridae sp. 1 & 3 & 0 & Restricted \\
\hline & Geometridae sp. 2 & 0 & 1 & Restricted \\
\hline & Stenalcidia sp. 1 & 0 & 5 & NI \\
\hline & Stenalcidia sp. 2 & 1 & 0 & Restricted \\
\hline \multirow{8}{*}{ Limacodidae } & Limacodidae sp. 1 & 0 & 1 & Polyphagous \\
\hline & Limacodidae sp. 2 & 0 & 1 & NI \\
\hline & Limacodidae sp. 3 & 1 & 0 & NI \\
\hline & Limacodidae sp. 4 & 2 & 0 & $\mathrm{NI}$ \\
\hline & Limacodidae sp. 5 & 2 & 0 & NI \\
\hline & Miresa clarissa (Stoll, 1790) & 0 & 1 & Polyphagous \\
\hline & Platyprosterna perpectinata (Dyar, 1905) & 5 & 0 & Polyphagous \\
\hline & Semyra incisa (Walker, 1855) & 2 & 1 & Polyphagous \\
\hline \multirow{4}{*}{ Megalopigydae } & Megalopyge albicollis (Schauss, 1900) & 0 & 1 & Polyphagous \\
\hline & Megalopyge braulio Schauss, 1924 & 0 & 1 & Polyphagous \\
\hline & Norape sp. & 4 & 3 & Polyphagous \\
\hline & Podalia annulipes (Boisduval, 1833) & 0 & 1 & Polyphagous \\
\hline \multirow{4}{*}{ Noctuidae } & Cydosia mimica (Walker 1866) & 0 & 1 & Restricted \\
\hline & Cydosia punctistriga (Schauss, 1904) & 0 & 1 & NI \\
\hline & Eloria subapicalis (Walker, 1855) & 0 & 7 & Restricted \\
\hline & Noctuidae sp. & 0 & 1 & Restricted \\
\hline Notodontidae & Heterocampa sp. & 7 & 12 & Polyphagous \\
\hline \multirow{2}{*}{ Oecophoridae } & Inga haemataula (Meyrick, 1911) & 6 & 1 & Polyphagous \\
\hline & Inga phaeocrossa (Meyrick, 1912) & 1 & 0 & Polyphagous \\
\hline Pyralidae & Carthara abrupta (Zeller, 1881) & 12 & 3 & Polyphagous \\
\hline \multirow{2}{*}{ Riodinidae } & Emesis sp. & 1 & 0 & Polyphagous \\
\hline & Hallonympha paucipuncta (Spitz, 1930) & 0 & 1 & Polyphagous \\
\hline Saturniidae & Hylesia schuessleri Strand, 1934 & 1 & 0 & Polyphagous \\
\hline Tortricidae & Platynota rostrana (Walker, 1863) & 0 & 3 & Polyphagous \\
\hline Urodidae & Urodus sp. & 0 & 5 & Restricted \\
\hline \multirow{2}{*}{ Unidentified } & sp. 1 & 1 & 0 & $\mathrm{NI}$ \\
\hline & sp. 2 & 1 & 1 & $\mathrm{NI}$ \\
\hline
\end{tabular}

${ }^{*}$ Indicates the five commonest species. 


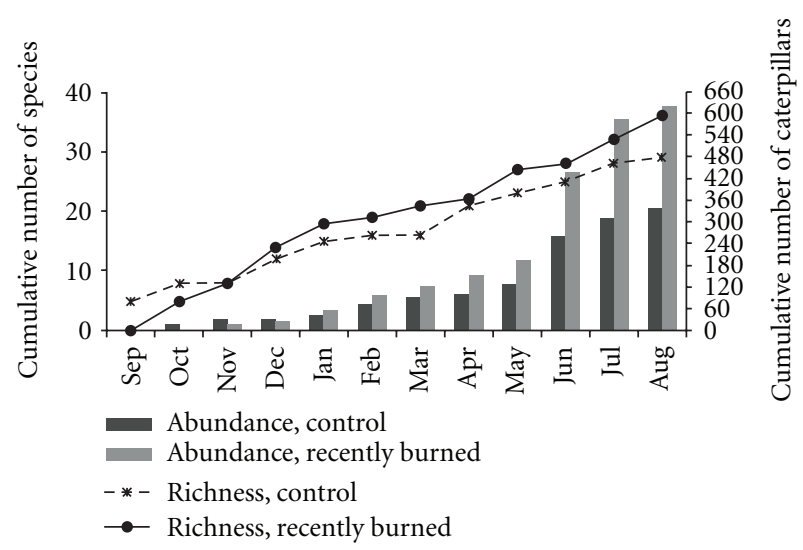

Figure 2: Cumulative number of caterpillars (bars) and species (rows) in two areas of cerrado sensu stricto in the FAL (recently burned and control) from September 2005 to August 2006.

sampling effort and showed a greater increase during the dry season, specifically during May and June (Figure 2).

\section{Discussion}

The sporadic and accidental fires in restricted areas of the cerrado may act to renew the vegetation [19], allowing the reoccupation of sites more rapidly by plant species. Several studies in tropical forests and in the cerrado have shown the importance of sprouting as a mechanism of postfire regeneration of shrub and tree species [28-32]. The new foliage that results from sprouting attracts a variety of herbivores.

In the cerrado, a low frequency of caterpillars on host plants is a common feature [20,33-35]. However, recent fire in the cerrado study area produced as $4.7 \%$ increase in the frequency of caterpillars on plants of Erythroxylum. The reason for this increase may be that fire may benefit herbivores by increasing the availability of resources. This high availability of resources results from the regrowth of plants because many new leaves are synchronously produced.

Although species richness did not differ between areas, the higher dominance observed in the burned area suggests a higher diversity in the control area. The most interesting feature of this system is the increase of rare species in the burned area. This increase may result from intense regrowth, which may produce new oviposition sites and new environments for these species. At the same time, nearby areas were available to act as a source for re-colonization [17]. However, the rarefaction curves did not reach an asymptote. In fact, previous studies $[23,36]$ indicate that species caterpillars not found in our surveys occur on the two species of Erythroxylum that were examined. These additional species include Erynnis funeralis (Scudder \& Burgess, 1870) (Hesperiidae), Phobetron hipparchia (Cramer, [1777]) (Limacodidae) and Automeris bilinea Walker, 1855 (Saturniidae). These species are all polyphagous and could be present on other species of host plants.
The variation in the abundance of insects in the cerrado occurs regardless of the passage of fire and remains seasonal [37]. However, the mortality caused by fire produces an immediate reduction in population size. Even, one month after the fire, caterpillars were not found on the plants surveyed. Moreover, the caterpillar abundance on both species of plants during all the subsequent months was higher in the area disturbed by the recent fire. Similar results have been found for adults of certain insect orders, such as Coleoptera, Hemiptera, Hymenoptera and Lepidoptera, in the cerrado of Brasilia [37]. The return to the previous levels of abundance depends on the order to which the insect belongs and ranges from two to more than thirteen months after the occurrence of the fire [3]. Up to 12 months after the occurrence of fire, the abundance of caterpillars associated with the Erythroxylum species studied here had not returned to a level comparable with that observed in the control area.

Research conducted in the same region with the community of caterpillars associated with Byrsonima (Malpighiaceae), showed that if the fire in the cerrado is recurrent every two years during the dry season, the results are quite different [38] from those previously discussed. In this case, the abundance and species richness of caterpillars in areas with frequent fires were markedly less than the abundance and species richness of caterpillars in areas protected from fire for more than 30 years. These results are consistent with other previous reports that fire reduces the populations of caterpillars [39], and may cause local extinction of some species [40]. However, these results from areas with frequent fires are in contrast to the results found if the fires are accidental and sporadic, as in the case of this study.

Even with smaller losses than those caused by recurrent fires, the recent accidental fire dramatically increased the abundance of caterpillars and as result, the attacks on plants in the postfire period, just at the time at which most synchronous leaf production in the cerrado occurs. For this reason, this process may produce extensive damage to vegetation and may harm biodiversity conservation in the region. Furthermore, a scheme of recurrent burns during several years in the same area results in the biological and physicochemical degradation of the soil and thus in the reduction of aerial biomass [41].

Although we did not replicate each treatment, our results reflect the effect of fire, as we have followed the changes in communities of caterpillars on various plant species for several years in protected areas from fire [21, 23, 38, 42], and in addition, we have surveyed caterpillars on other plant species in postfire conditions, with similar results (unpublished data). Furthermore, some studies suggest the impossibility of replication treatments when it comes from natural phenomena occurring on a large scale, as in the case of burning [43]. Thus, the results of this study indicate that the recent accidental fire had the following effects on the external folivorous caterpillars: (a) killed eggs and larvae at first but had a positive effect on the relative abundance of caterpillars up to one year postfire, (b) increased the frequency of caterpillars associated with two Erythroxylum species in the cerrado, (c) did not affect the richness of caterpillars on these plants and (d) changed the caterpillar 
species composition because the effects of the fire promoted increases of rare or opportunistic species.

\section{Acknowledgments}

The authors are grateful to Vitor O. Becker for the identification of the Lepidoptera and to the Administrators of the Experimental Station (Fazenda Água Limpa-FAL) of the University of Brasilia for facilitating our field work. C. Lepesqueur was granted a scholarship by CAPES, and I. R. Diniz was granted an award from CNPq (Research Productivity Grant). The project was financially supported by $\mathrm{CNPq}$ and FAPDF.

\section{References}

[1] L. M. Schoonhoven, J. J. A. Van Loon, and M. Dicke, Eds., Insect-Plant Biology, Oxford University Press, Oxford, UK, 2005.

[2] T. J. Massad and L. A. Dyer, "A meta-analysis of the effects of global environmental change on plant-herbivore interactions," Arthropod-Plant Interactions, vol. 4, no. 3, pp. 181-188, 2010.

[3] I. R. Diniz and H. C. Morais, "Efeitos do fogo sobre os insetos herbívoros do Cerrado: consensos e controvérsias," in Efeitos do Regime do Fogo Sobre a Estrutura de Comunidades de Cerrado: Resultados do Projeto Fogo, H. S. Miranda, Ed., pp. 121131, Ibama, Brasília, Brazil, 2010.

[4] R. Panzer and M. W. Schwartz, "Effectiveness of a vegetationbased approach to insect conservation," Conservation Biology, vol. 12, no. 3, pp. 693-702, 1998.

[5] M. F. Simon, R. Grether, L. P. De Queiroz, C. Skemae, R. T. Pennington, and C. E. Hughes, "Recent assembly of the Cerrado, a neotropical plant diversity hotspot, by in situ evolution of adaptations to fire," Proceedings of the National Academy of Sciences of the United States of America, vol. 106, no. 48, pp. 20359-20364, 2009.

[6] L. M. Coutinho, "Fire in the ecology of the Brazilian cerrado," in Fire in the Tropical Biota-Ecosystem Processes and Global Challenges, J. G. Goldammer, Ed., pp. 82-105, Springer, Berlin, Germany, 1990.

[7] H. S. Miranda, M. M. C. Bustamante, and A. C. Miranda, "The fire factor," in The Cerrados of Brazil: Ecology and Natural History of a Neotropical Savanna, P. S. Oliveira and R. J. Marquis, Eds., Columbia University Press, New York, NY, USA, 2002.

[8] M. I. Miranda and C. A. Klink, "Colonização de campo sujo de cerrado com diferentes regimes de queima pela gramínea Echinolaena inflexa (Poaceae)," in Impactos de Queimadas em Áreas de Cerrado e Restinga, H. S. Miranda, C. H. Saito, and B. F. S. Dias, Eds., pp. 46-52, UnB, Brasilia, Brazil, 1996.

[9] E. A. De Castro and J. B. Kauffman, "Ecosystem structure in the Brazilian Cerrado: a vegetation gradient of aboveground biomass, root mass and consumption by fire," Journal of Tropical Ecology, vol. 14, no. 3, pp. 263-283, 1998.

[10] W. A. Hoffmann, "Post-burn reproduction of woody plants in a neotropical savanna: the relative importance of sexual and vegetative reproduction," Journal of Applied Ecology, vol. 35, no. 3, pp. 422-433, 1998.

[11] E. P. Rocha e Silva, Efeito do regime de queima na taxa de mortalidade e estrutura da vegetação lenhosa de campo sujo de cerrado [M.S. thesis], Universidade de Brasília, Brasília, Brazil, 1999.
[12] H. S. Miranda, Efeitos do Regime de Fogo Sobre a Estrutura de Comunidaaes de Cerrado: Resultados de Projeto Fogo, Ibama, Brasília, Brazil, 2010.

[13] H. C. Morais and W. W. Benson, "Recolonização de vegetação de Cerrado após queimada, por formigas arborícolas," Revista Brasileira de Biologia, vol. 48, pp. 459-466, 1988.

[14] M. Prada, O. J. Marini-Filho, and P. W. Price, "Insect in lower heads of Aspilia foliacea (Asteraceae) after a fire in a central Brazilian savanna: evidence for the plant vigor hypothesis," Biotropica, vol. 27, pp. 513-518, 1995.

[15] R. P. B. Henriques, M. X. A. Bizerril, and A. R. T. Palma, "Changes in small mammal populations after fire in a patch of unburned cerrado in Central Brazil," Mammalia, vol. 64, no. 2, pp. 173-185, 2000.

[16] M. A. Marini and R. B. Cavalcanti, "Influência do fogo na avifauna do sub-bosque de uma mata de galeria do Brasil central," Revista Brasileira de Biologia, vol. 56, pp. 749-754, 1996.

[17] O. J. Marini-Filho, "Distance-limited recolonization of burned cerrado by leaf-miners and gallers in central Brazil," Environmental Entomology, vol. 29, no. 5, pp. 901-906, 2000.

[18] A. B. Swengel, "A literature review of insect responses to fire, compared to other conservation managements of open habitat," Biodiversity and Conservation, vol. 10, no. 7, pp. 11411169, 2001.

[19] M. B. Medeiros and H. S. Miranda, "Mortalidade pós-fogo em espécies lenhosas de campo sujo submetido a três queimadas prescritas anuais," Acta Botânica Brasílica, vol. 19, pp. 493-500, 2005.

[20] P. W. Price, I. R. Diniz, H. C. Morais, and E. S. A. Marques, "The abundance of insect herbivore species in the tropics: the high local richness of rare species," Biotropica, vol. 27, no. 4, pp. 468-478, 1995.

[21] I. R. Diniz and H. C. Morais, "Lepidopteran caterpillar fauna of cerrado host plants," Biodiversity and Conservation, vol. 6, no. 6, pp. 817-836, 1997.

[22] V. Novotný and Y. Basset, "Rare species in communities of tropical insect herbivores: pondering the mystery of singletons," Oikos, vol. 89, no. 3, pp. 564-572, 2000.

[23] M. S. Milhomem, H. C. Morais, I. R. Diniz, and J. D. Hay, "Espécies de lagartas em Erythroxylum spp. (Erythroxylaceae) em um cerrado de Brasília," in Contribuição ao Conhecimento Ecológico do Cerrado, L. L. Leite and C. H. Saito, Eds., pp. 107111, UnB, Brasília, Brazil, 1997.

[24] D. L. Ayres and A. S. Santos, Bioestat 5.0: Aplicações Estatísticas nas Áreas das Ciências Biológicas e Médicas: Desenvolvimento Estatístico, Mamirauá \& MCT/CNPq, Brasília, Brazil, 2005.

[25] H. L. Sanders, "Marine benthic diversity: a comparative study," The American Naturalist, vol. 102, pp. 243-282, 1968.

[26] N. J. Gotelli and G. L. Entsminger, EcoSim: Null Models Software for Ecology, Acquired Intelligence Inc. \& Kesey-Bear, Jericho, Vt, USA, 2011.

[27] W. C. Rodrigues, "Dives—diversidade de espécies," 2005, http://www.ebras.bio.br/dives/.

[28] C. Uhl, K. Clark, and H. Clark, "Successional patterns associated with slash-and-burn agriculture in the upper Rio Negro region of the Amazon Basin," Biotropica, vol. 14, no. 4, pp. 248-254, 1982.

[29] J. B. Kauffman, "Survival by sprouting following fire in tropical forests of the eastern Amazon," Biotropica, vol. 23, no. 3, pp. 219-224, 1991.

[30] T. T. Castellani and W. H. Stubblebine, "Sucessão secundária inicial em mata tropical mesófila, após perturbação por fogo," Revista Brasileira de Botânica, vol. 16, pp. 181-203, 1993. 
[31] A. S. Penha, Propagação vegetativa de espécies arbóreas a partir de raizes gemíferas: representatividade na estrutura fitossociológica e descrição dos padrões de rebrota de uma comunidade florestal, Campinas, São Paulo [M.S. thesis], Universidade Estadual de Campinas, Campinas, Brazil, 1998.

[32] S. V. Martins, G. A. Ribeiro, W. M. Silva Junior, and M. E. Nappo, "Regeneração pós-fogo em um fragmento de floresta estacional semidecidual no município de Viçosa, MG," Ciência Florestal, vol. 12, pp. 11-19, 2002.

[33] I. Andrade, I. R. Diniz, and H. C. Morais, "A lagarta de Cerconota achatina (Zeller) (Lepidoptera, Oecophoridae, Stenomatinae): biologia e ocorrência em plantas hospedeiras do gênero Byrsonima Rich (Malpighiaceae)," Revista Brasileira de Zoologia, vol. 12, pp. 735-741, 1995.

[34] H. C. Morais, I. R. Diniz, and J. R. Silva, "Larvas de Siderone marthesia nemesis (Illiger) (Lepidoptera, Nynphalidae, Charaxinae) em um cerrado de Brasília, Distrito Federal, Brasil," Revista Brasileira de Zoologia, vol. 13, pp. 351-356, 1996.

[35] S. Scherrer, I. R. Diniz, and H. C. Morais, "Climate and host plant characteristics effects on lepidopteran caterpillar abundance on miconia ferruginata DC. and miconia pohliana Cogn (Melastomataceae)," Brazilian Journal of Biology, vol. 70, no. 1, pp. 103-109, 2010.

[36] I. R. Diniz, H. C. Morais, and A. J. A. Camargo, "Host plants of lepidopteran caterpillars in the Cerrado of the Distrito Federal," Revista Brasileira de Entomologia, vol. 45, pp. 107-122, 2001.

[37] I. R. Diniz, Variação na abundância de insetos no cerrado: efeitos das mudanças climáticas e do fogo [Ph.D. thesis], Universidade de Brasília, Brasília, Brazil, 1997.

[38] I. R. Diniz, B. Higgins, and H. C. Morais, "How do frequent fires in the Cerrado alter the lepidopteran community?" Biodiversity and Conservation, vol. 20, no. 7, pp. 1415-1426, 2011.

[39] C. S. Crawford and R. F. Harwood, "Bionomics and control of insects affecting Washington grass seed fields," Technical Bulletin of the Agricultural Experimental Station, vol. 44, pp. 1-25, 1964.

[40] S. R. Swengel and A. B. Swengel, "Relative effects of litter and management on grassland bird abundance in Missouri, USA," Bird Conservation International, vol. 11, no. 2, pp. 113-128, 2001.

[41] E. L. Cardoso, S. M. A. Crispim, C. A. G. Rodrigues, and W. Barioni Júnior, "Efeitos da queima na dinâmica da biomassa aérea de um campo nativo do Pantanal," Pesquisa Agropecuária Brasileira, vol. 38, pp. 747-752, 2003.

[42] H. C. Morais, J. D. V. Hay, and I. R. Diniz, "Brazilian cerrado folivore and florivore caterpillars: how different are they?" Biotropica, vol. 41, no. 4, pp. 401-405, 2009.

[43] P. Van Mantgem, M. Schwartz, and M. Keifer, "Monitoring fire effects for managed burns and wildfires: coming to terms with pseudoreplication," Natural Areas Journal, vol. 21, no. 3, pp. 266-273, 2001. 

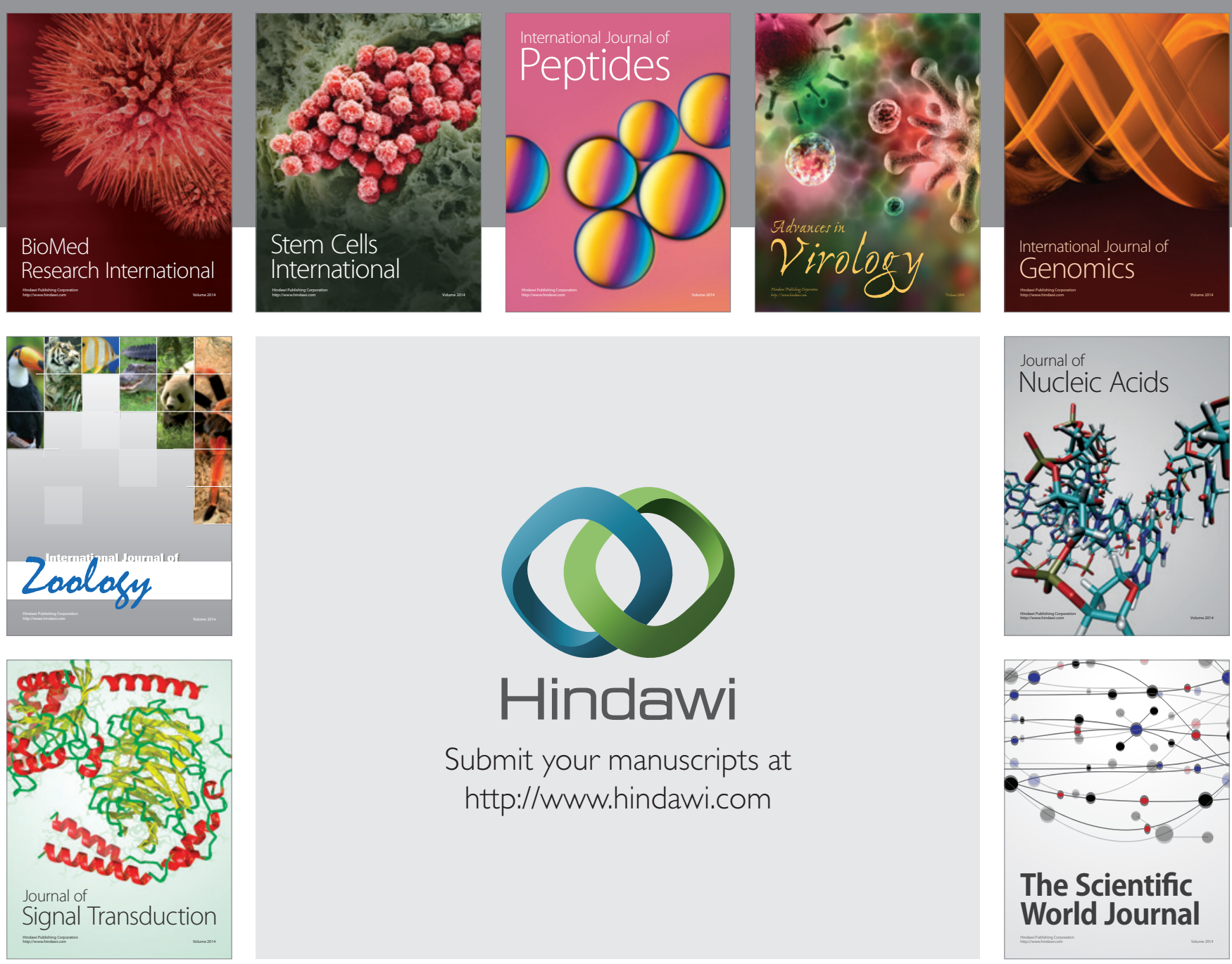

Submit your manuscripts at

http://www.hindawi.com
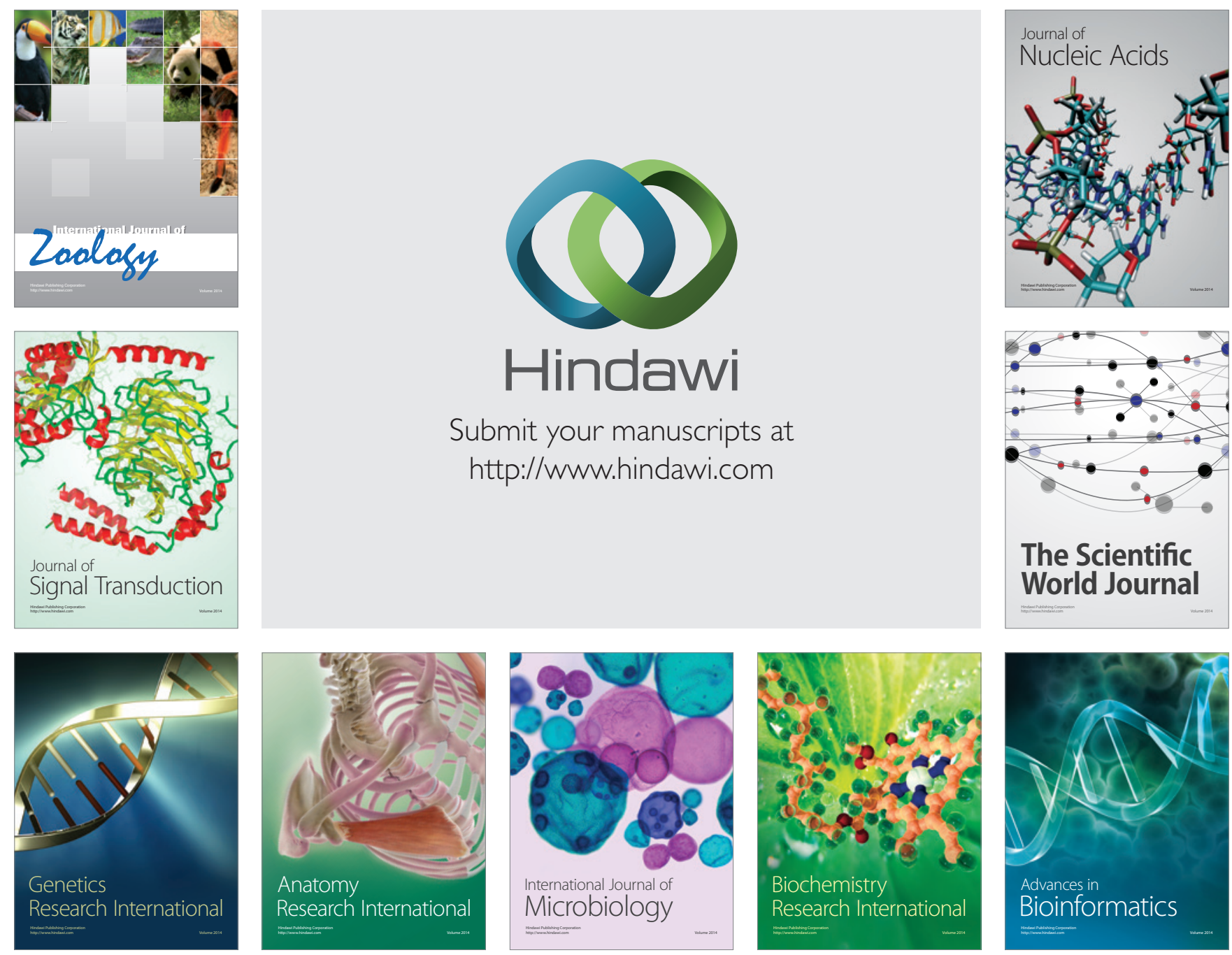

The Scientific World Journal
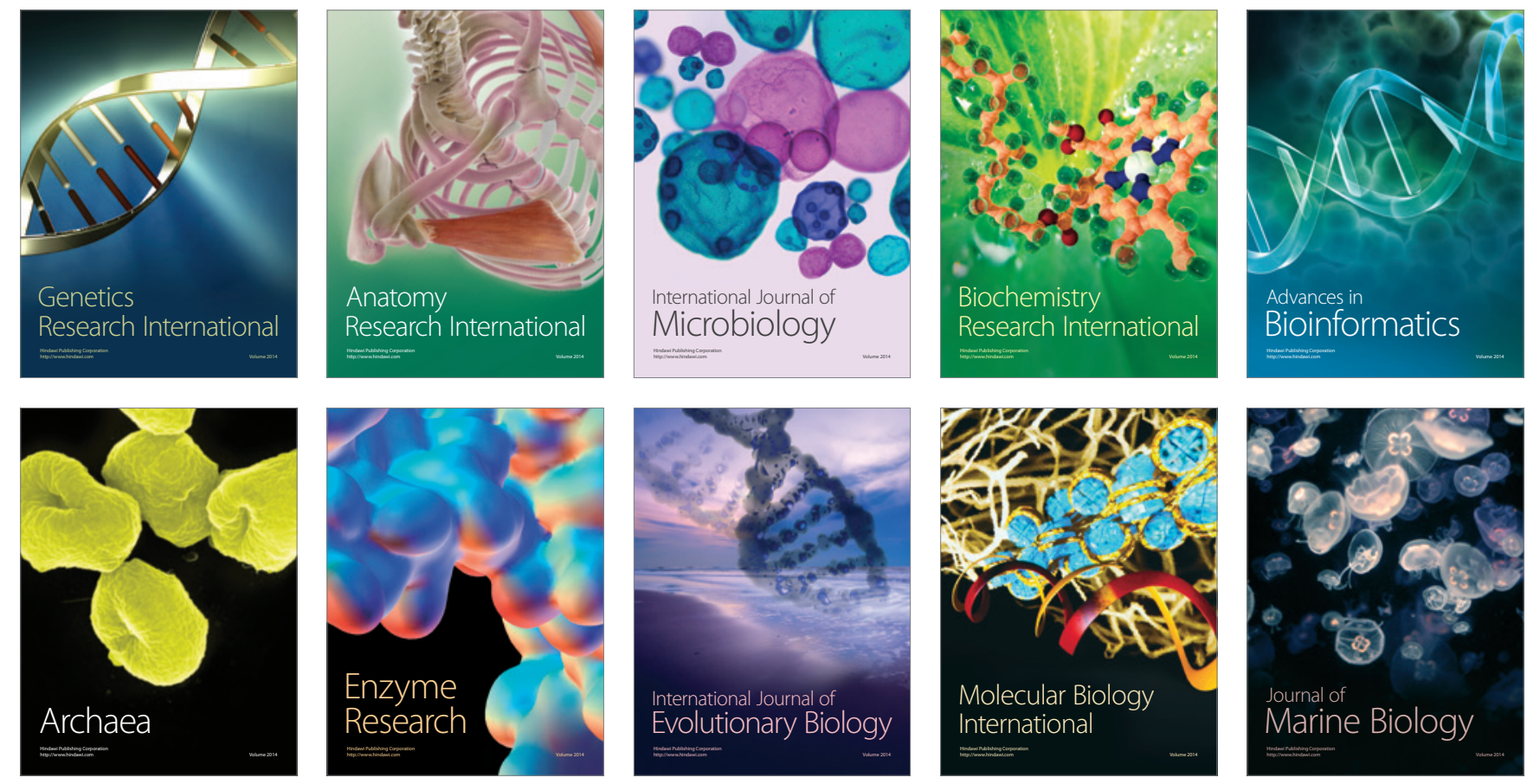